\title{
The Level of Desirability of Information Technology Systems and Its Relation with Organizational Commitment
}

\author{
Dr. Sayyed Mohsen Allammeh \\ School of Official affairs and Economics, University of Isfahan, Iran \\ Tel: 0098-3117-934-305 E-mail: dr_allame@yahoo.com
}

Hamidreza Shavaran

School of Educational Sciences and Psychology, University of Isfahan,Iran

Tel: 0098-3117-934-206 E-mail: Rezashavaran@yahoo.com

Dr. Azizollah Dabaghi

School of Foreign Languages

University of Isfahan, Iran

Tel: 0098-3117-933-100Ｅ-mail: dabaghi@fgn.ui.ac.ir

Azizollah Arbabisarjou (Corresponding Author)

School of Educational Sciences and Psychology, University of Isfahan,Iran

Tel: 0098-3117-932-540Ｅ-mail: Arbabisarjou2007@gmail.com

Received: April 12, 2011 Accepted: April 18, 2011 doi:10.5539/hes.v1n1p109

\begin{abstract}
Purpose - This paper aims to define Information Technology (IT) desirability and determine IT relationship with organizational commitment. The existence of such a relationship between IT \& organizational commitment can guide the organizational leaders to promote and to develop the IT potentials in order to improve the performance of employees, and elevate job satisfaction, commitment and organizational effectiveness.

Design /methodology /approach -The design of the research is descriptive - correlational and the statistical sample consists of 84 educational service experts working at educational service offices in the University of Isfahan. They were selected based on purposeful sampling.

Findings - The results showed that among IT desirability components, two components of training and fitness had a significant relationship with continuance commitment (one of the organizational commitment dimensions).

Research limitations - since the statistical sample was selected purposefully and the research was done on educational service experts, any generalization of the results to other organizations and employees requires caution.

Practical implications - Since the results of the research show the existence of only one of the dimensions of organizational commitment ( continuance commitment) and two components of desirability of IT ( fitness and training), managers can try to improve the levels of these dimensions of IT.

Originality / value - many researchers have investigated different effects and relations between IT and employees, but in this research the aim has been to investigate a more complete account as well as different aspects of employees' perceptions about IT (i.e. desirability of the system).
\end{abstract}

Keywords: Information technology, System, Organizational commitment, Employees, Desirability, University of Isfahan

\section{Introduction}

Nowadays, most organizations benefit from or depend on Information Technology. This indicates the power of the new knowledge in organization transformation which may affect the personnel attitudes. One attitude that may be 
influenced is organizational commitment. Typology studies of Zuboff (1988) and Clegg \& Corbett (1986) are among the first studies on the influence of Information Technology (IT) on individual function. They found that automated technology reduces the employees' motivation, while it increases the mechanistic aspects of the job and hence decreases the employees' attitudes. Also, McMahan (1993) and Wall \& et al. (1990) showed that applying IT influences the motivational nature of jobs negatively. Wall et al. (1990) believed that since technology needs high efficiency and repetitive activities and taking potential resources of employees for high level of mental activities, it is expected that individuals have less job satisfaction, organizational commitment, and motivation for executing tasks. Supar et al. (2005) believe that the lack of employee participation in sharing knowledge which results in improvement of the organization; may affect their attitude negatively. In other words, if the employees take part in organization knowledge, we expect better performance and achievement. Allameh (2006) suggests that although IT is necessary for understanding and applying the management of new knowledge, the challenge for today's managers is simultaneous management of technological and human aspects of organization.

\subsection{Desirability of Information Technology System}

The organization must create an environment for sharing, transferring, and contrasting knowledge among its members in order to guide personal knowledge along the organizational goals (Nonaka \& Takeuchi, 1995). Certainly, the more efficient the organization in processing data, the more powerful it is in producing information. Using advanced computers and communication networks are effective tools in deriving data in an organization.

IT has a great potential in facilitating organizational learning and knowledge management in organization structure and it is turning into a critical issue in organizations (Issa \& Haddad 2007). Therefore, the relative level of desirability of IT can result in resolving problems, achievements and developments in universities and schools, enhancing social status, creating and enriching jobs and professions and other developments in relevant systems and organizations. Organization consists of personal experiences, social relations, and technology.

Tomilson (2002) suggested it is critical that organizations keep the leading edge by having their employees well trained in the latest technologies. After surveying the research literature about IT systems and their application in organizations, it was found that various researchers have investigated different aspects of IT and their relationship with employees. Therefore, the present researcher has tried to survey this aspect from a different point of view i.e. desirability of the system that reflects the employees' perceptions and views. Therefore, what can describe the impact of IT in the organization is the categorization of the desirability of IT into components which can be easily measured. Hence, the researchers have categorized the relative desirability into four components of support, access, fitness with organization, and training employees and users (SAFT).

\subsection{Support}

In general, the physical facilities of IT consist of instruments such as computer hardware, additional technology and communication tools. These are, of course tangible assets and are measured and covered by a global standard (Mayole, 2004). These tangible assets have the role of supporting successful IT programs and integrating technology, and must not be ignored. Although these assets, which are considered as organizations and companies' expenditures and costs, have the potential to create values and effects necessary for transferring, producing, processing and applying information resources if used properly and according to social needs. These costs are called Total Cost Ownership (TCO), which were used by Granter Incorporation. Granter Inc., as the biggest private company in information technology consultation and research, has promoted itself in the world (Granter Inc., 2006). Another critical issue which is related to the support of the system is information security which is an important factor.

\subsection{Access}

It is possible to access technical resolutions, but to mange knowledge and information technology, organizations have to create an environment of contribution, participation and cooperation for sharing knowledge. According to Ernest \& Hung, 50\% of the professionals believe that changing human behavior is one of the executing problems in knowledge management (Glasser, 1998). Therefore providing access to the instruments of IT while people work in an organization can result in cooperation and participation, and has a definite role in creating employees' commitment and their gaining technical knowledge. Accessing, providing and distributing hardware and software properly can be essential in integrating technology. However, integrating ICT and project-based perspectives needs a high degree of technological network tools (Hearington, 2006). Technology can be applied through creating methods to process, deliver and share valuable information which is necessary to produce knowledge among individuals. 
Pan and Scarborough (1998) summarized the socio - technical analysis in terms of three major layers of KM systems: infrastructure: hardware / software info structure; rules, info culture; stock of background knowledge (Issa \& Haddad 2007). In general, this component consists of the rate of access to and applying IT to employees, providing general facilities and computer programs for executing organization affairs and communicating with other employees in the organization.

\subsection{Training Employees}

Even the best computer programs and infrastructures for IT, and the highest support are void if not used by employees. So, the growth and development of individuals and employees of the organizations increase with this vital technology. The employees of an organization are considered as its mental assets. Knowledge and other mental assets are accounted intangible assets for the organization. Organizations will gain and maintain their competitive advantage by applying systematic learning and creating knowledge capital by externalizing and applying it through innovative activities in products, services and processes (Adams \& Lamont, 2003).

In other words, offering training to employees results in organizational learning and it is in this process that implicit knowledge will optimally turn into explicit knowledge. Organizations will enhance their major competencies by enabling organizational learning, and innovation through producing knowledge (Allameh, 2005). Accordingly, providing in-service training, introducing employees to other organizations and companies to get certificates such as International Computer Driving License (ICDL) as well as programming and practical experiences are among training methods for employees.

\subsection{Fitness}

The concept of fitness is derived from literatures related to development management and organizational transformations. In the author's viewpoint, if IT, either in the hardware or software field, does not fit to goals, missions, employees' situations, environments, structures and culture, it will lead to two major consequences: It will not only result in the retardation of the development process toward goals, but will also result in negative attitudes and the lack of employees' commitment. This endangers the effectiveness and efficiency of the organization. Tushman and Nadler believe that a model of organization development and transformation is useful, because it not only describes the components of the organization but also considers the dynamic relations between various components (Heys, 2006). In their viewpoint, the rate of fitness consists of adaptation between the needs, goals and structures of any components with other components. According to them, the more the fitness between the organization's factors and variables, the more effective the organization's behavior. Fitness between the job and formal organizations is one of the important points that must be considered in information technology system and one of the designing elements that must fit with the organization is its information technology system (Cummings, 2008). But the fitness of the organization with a system without skill, attitude and human commitment will not result in any competitive advantages.

Thus, the focus is on developing committed employees who can be trusted to use their discretion to carry out job tasks in ways that are consistent with organizational goals (Eisenhardt, 1985, Storm \& Roodt, 2002).

\subsection{Organizational Commitment}

Organizational commitment is a concept related to the individuals' attitude. Each person's attitude to his/her job indicates his/her negative or positive evaluation of the aspects of the work environment (Robbins, 1998).

Allen and Meyer (1990) describe commitment as a psychological state that binds the individual to the organization. The concept of organizational commitment has attracted considerable interest in an attempt to understand and clarify the intensity and stability of an employee's dedication to the organization (Mester, Visser, Roodt \& Kellerman, 2003).

According to Meyer and Allen (1997) the concept of organizational commitment is a construct distinguishable from other familiar concepts such as job satisfaction, job involvement, career salience, occupational commitment, turnover intentions, work group attachment and protestant work ethic (Cohen, 1993; Mathieu \& Farr, 1991; Meyer, Allen \& Smith , 1993; Morrow \& McElory, 1986; Mueller, Wallance \& Price , 1992).

Meyer and Herescovitch (2001) suggest that the binding force of commitment is experienced as a mindset (i.e. a frame of mind or psychological state that compels an individual toward a course of action). The mindsets reflect three distinguishable themes which Meyer and Allen (1991) label as affective commitment, continuance commitment, and normative commitment. These three distinguishable components of organizational commitment reflect a difference between a preference to stay with the present organization arising out of a sense of emotional attachment (affective commitment), compared to one rooted in a sense of economic necessity or the perceived cost 
of leaving (continuance commitment) or of moral obligation (normative commitment). (Dockell, Basson and Coetzee, 2006). Meyer and Herescovitch (2001) developed some propositions that encompass the development of the different mindsets.

\subsection{Affective Commitment}

Affective commitment (the mindset of desire) develops when an individual becomes involved in, then recognizes the value - relevance of, and / or derives his or her identity form, association with an entity or pursuit of a course of action.

Employees who have strong confidence in their abilities and achievements have higher affective commitment. A possible explanation for the observed relation between the two variables is that competent people are able to choose higher quality organization, which in turn inspires affective commitment (Mathieu \& zajac, 1990). Affective commitment has shown a positive correlation with job scope- a composite of three variables- that is, job challenge, degree of autonomy and variety of skills used. Affective commitment to the organization is stronger among employees whose leaders allow them to participate in decision making (Rhodes \& steers, 1981) and those who treat them with consideration (Decotiis \& Summers, 1987).

\subsection{Continuance Commitment}

Continuance commitment (the mindset of perceived cost) develops when individuals find no way to maintain their capital unless they take certain measures in a course to a goal. It refers to the employees' sacrifices (i.e. losing their jobs or pension benefits) resulting from terminating employment. Therefore, the employee becomes aware of the costs that are associated with leaving the organization (Dockell, Basson \& Coetzee, 2006).

Meyer and Allen (1997) show continuance commitment related to employees' perceptions about the transferability of their skills to other organizations. Employees who thought their training investments were less easily transferable elsewhere expressed stronger continuance commitment to their current organization. Employees whose primary link to the organization is based on strong continuance commitment stay with the organization not for reasons of emotional attachment, but because of a recognition that the costs associated with doing other wise are simply too high. All things being equal, there is no reason to expect that such employees will have a particularly strong desire to contribute to the organization (Meyer \& Allen, 1997).

\subsection{Normative Commitment}

Normative commitment (the mindset of obligation) develops as a result of the internalization of norms through socializing the receipt of benefits that induces a need to reciprocate, and / or acceptance of the terms of a psychological contract. (Dockell, Basson and Coetzee, 2006). Meyer and Allen (1997) suggest that normative commitment develops the basis of a particular kind of investment that the organization makes in the employee, specifically investments that seem difficult for employees to reciprocate (Meyer \& Allen, 1991; Scholl, 1981) and Individuals must comply with accepted norms and even accept them. Strong normative commitment involves being tied to the organization by feeling of obligation and duty. It is expected that normative commitment to organization will be positively related to such work behaviors as job performance, work attendance and organizational citizenship.

Sethi, Meinert, king and sethi (1996) suggest that organizations need to re - examine policies that lead to building commitment.

Commonly employed strategies such as pension plan, participation in stock options and development of organizational specific skills may in fact be working against the organization. Some employees may find themselves in a position where they want to quit, but may not be able to afford to do so. Some may be motivated to do just enough to maintain their jobs. In these cases, commitment fostering steps may actually be counterproductive. Meta analytic evidence suggests that age and organizational commitment are significantly, albeit weakly, related (Mathieu $\&$ Zajac, 1990). This relationship exists even when variable that are often confounded with age (organizational and position tenure) are controlled (Allen \& Meyer 1993).

Accordingly, it is expected that the rate of the relative level of the desirability of information technology has a positive relation with the components of organizational commitment, addressed by Meyer \&Allen (1991). Therefore, the purpose of this study is to find out if there is any significant relation between the components of desirability of information technology and organizational commitment (See Figure 1).

\section{Research Questions}

i. Is there any significant relation between the component of support of desirability of information technology and organizational commitment? 
ii. Is there any significant relation between the component of access to desirability of information technology and organizational commitment?

iii. Is there any significant relation between the component of employees' training in desirability of information technology and organizational commitment?

iv. Is there any significant relation between the component of fitness to desirability of information technology and organizational commitment?

\section{Research Methodology and Data Collection}

Regarding the fact that the researcher intends to determine the relation between the desirability of IT and organizational commitment of employees, the method of the present research is descriptive-correlational and results are obtained from completed questionnaires. The statistical population consists of employees of Isfahan University and the purposeful sample includes 84 educational service experts in educational service offices at different faculties. The educational service experts are individuals who offer service such as enrollment, units selecting, omitting, adding and changing units, following the education trend up, exchanging students, entering the scores and announcing the graduation and issuing the degrees and most of affairs are done by computer and information system. Two kinds of questionnaires were used:

\subsection{Organization Commitment Questionnaire (OCQ)}

It was developed by Meyer \& Allen (1987) and consists of 24 questions based on the Likert five-point scale (completely agree, agree, no idea, disagree, completely disagree) with scores of $5,4,3,2$, and 1 , respectively. The questionnaire deals with organizational commitment the in three dimensions of affective commitment, continuance commitment and normative commitment. Meyer \& Allen (1987) reported the reliability of the test, 0.86. In addition, the reliability coefficient was obtained at 0.84 in the present study after performing a pilot study and determining the questions' variance coefficient.

\subsection{Desirability of Information System Questionnaire (SAFT)}

This is a researcher - made questionnaire and has four components which were designed for desirability of information system (Support, Access, Fit and Training), based on a review of literatures about establishing and applying information technology systems. The questionnaire consists of 40 closed-ended questions with 5 options which are very high, high, moderate, and very low. The content validity of the questionnaire was confirmed by the experts in the field and its reliability was determined 0.95 through Alpha Cronbach's coefficient, after performing a pilot study and defining the question variance coefficient.

\section{Findings}

The findings are presented as the following sentences (based on research questions):

i. The results from the regression coefficient at a level of $\alpha=0.05$ showed that there is no significant relation between the component of support and dimensions of organizational commitment. In other words, the desired support for information technology in the University of Isfahan has no significant relation with the three dimensions, affective commitment, continuance commitment and normative commitment of employees (Table 1, Figure 2).

ii. The results from the regression coefficient at a level of $\alpha=0.05$ showed that there is no significant relation between the component of access and dimensions of organizational commitment. In other words, the desired access to information technology in the University of Isfahan has no significant relation with the three dimensions, affective commitment, continuance commitment, and normative commitment of employees (Table 2, Figure 3).

iii. The results from regression coefficient at level $\alpha=0.05$ showed that there is no significant relation between the component of fit with dimensions of affective and normative commitment of employees. But, the results showed that there is a significant relation between fit in the information technology system and continuance commitment (Table 3, Figure 4).

iv. The results from regression coefficient at level $\alpha=0.05$ showed that there is no significant relation between the component of training with dimensions of affective and normative commitment of employees. But, the results showed that there is a significant relation between training and training courses and continuance commitment of employees (Table 4, Figure 5).

\section{Discussion and Conclusion}

Information technology is considered an innovative and widespread phenomenon, having bilateral effects on the psychological and social status of employees. Changes in the concept of communication structures and the way 
activities are done and the challenging of traditional methods have certainly had positive and negative effects on manpower and hence the organization. The present study was performed to investigate the relation between the desirability of information technology system and the employees' organizational commitment. Hence, the relation between each of the four components (support, access, fit, and training) and dimensions of organizational commitment (continuance, affective and normative) was investigated and the following results were obtained:

i. According to the results, an organizations' support for providing physical facilities such as hardware and software, additional technology and intangible communication instruments has no relation with the dimensions of affective, continuance and normative commitments of the employees of the organization and providing such facilities for better executing the affairs and improved application of IT can not be effective in improving their organizational commitment. These findings can be influenced by employees' attitude and it is the organization's duty to provide such facilities and lacking such facilities the work will face problems. Zuboff (1988) and Clegg \& Corbett (1986) showed that IT can increase employees satisfaction in terms of mechanical aspects, but can not influence their motivation and attitude positively. Accordingly, Wall \& et. Al (1990) confirm in their study that IT can not influence employees' motivation and attitude.

ii. Concerning the second question, the results showed that access to communication instruments such as hardware and software, technical resolutions, technology for virtual communications have no relation with the three dimensions of affective, continuance and normative commitments. Actually, providing such facilities for the better application of IT can not affect employees' attitude and it seems that employees believe that it is common to access communication facilities in information technology system and that the organization needs such facilities to prevent the loss of time and to execute affairs. Therefore, providing these facilities is part of an organization's duty in order to increase its profits. Allameh (2006) addresses the simultaneous management of both technological aspects and manpower and believes that the proper management of the technological aspects can not result in the positive attitude of employees per se, and other tools are needed to change attitudes and satisfy employees. Also, Van Beveren (2002) expresses that IT and its relevant technologies are very valuable in processing, delivering, and sharing and it is necessary for producing knowledge among the people, but how it influences the attitudes is what must be studied. Also, Supar \& et. al. (2005) showed in their studies that organization support and organizational culture can influence more employees' attitude and functions.

iii. The system's congruence to organization's goals and structure and the individual's need to meet these goals were only related to the continuance commitment of employees. It can also be influenced by the fact that employees know IT system in the organization proportional to the organization's goals, so this symmetry results in a positive attitude to the organization. Actually, they evaluate an organizations' affairs reasonably and the organizations' efforts to produce knowledge positively. Accordingly, Gann (2000) believes that IT can influence transferring knowledge and information among the work teams and result in developing new knowledge and hence result in satisfaction and positive attitude.

iv. The results obtained for the fourth question showed that training and creating professional opportunities as well as increasing the individual's abilities to use and apply IT system more optimally can only be related to continuance commitment and does not influence affective and normative commitment. It seems that providing new training about IT and increasing employees' knowledge can create technical skill and ability in them, and they feel more security in terms of survival within the organization.

According to the present study, the organization must work actively in providing appropriate ICTs and offering common and professional trainings. On the other hand, students, researchers and experts in information, communication and behavioral sciences must investigate the reasons for the lack of considerable relationship between an organization's access and support for and feelings, attitudes, dependency, and rationality of individuals in the organization.

As far as working in the University of Isfahan is concerned, due to the high limitations of work options, the university employees find it very difficult to find better positions outside the university. Therefore, it seems logical that they keep their present jobs and maintain their present status. On the other hand, they seek proper trainings to learn to work with the new technology in order to apply them to other opportunities outside their present working place in case they are forced to leave their jobs. It may be, therefore, that access and support from the system is at a level that does not entail affective commitment and dependency among employees. They may not comply with personal and informal values and normality of individuals. Perhaps, some of the requirements such as work 
challenge, degrees of autonomy, and various skills are not sufficiently met. These are the points that could be topics for further investigations.

\section{References}

Adams, G.L. \& Lamont, B.T. (2003). Knowledge management system and developing sustainable competitive advantage. Journal of knowledge Management, 7, 2, P.144. doi:10.1108/13673270310477342, http://dx.doi.org/10.1108/13673270310477342

Allameh, S.M. (2006). Passage from information revolution toward knowledge revolution: The Role of Information technology in organizational knowledge Creation .First conference of change management, university of Isfahan, (In Persian).

Allameh, S.M. (2005). Knowledge creation: Golden key of continuous innovation and sustainable competition. Journal of management, university of Isfahan, (In Persian) 15, pp 19-25.

Allen, N.J. \& Meyer, J.P. (1990). The measurement and antecedents of affective, continuance and normative Commitment to the organization. Journal of Occupational Psychology, 63, 1-18.

Allen, N.J. \& Meyer, J.P. (1993). Organizational commitment: Evidence of career stage effects? Journal of Business Research, 26, 49-61. doi:10.1016/0148-2963(93)90042-n, http://dx.doi.org/10.1016/0148-2963(93)90042-n

Clegg, C.W., \& Corbett, J.M. (1986). Psychological and organizational aspects of Computer aided manufacturing. Current Psychological Research and Reviews, 5, 189-204. doi:10.1007/bf02686613, http://dx.doi.org/10.1007/bf02686613

Cohen, A. (1993). On the discriminate validity of the Meyer and Allen (1984) measure of organizational Commitment: how does it fir with the work commitment contract? Organizational Behavior, 14, 82-91.

Cummings, T.G. (2008).Handbook of organization development, Sage. Publication.

Decotiis, T. A. \& Summers, T.P. (1987). A Path analysis of a model of the antecedents and consequences of organizational commitment. Human Relations, 40, 445- 470

Dockell, A. Basson, J. \& Coetzec, M. (2006). The effect of retention factors on organizational commitment: An investigation of high technology employees. Mcom dissertation University of South Africa.

Eisenhardt, K.M.(1985). Control: organizational and economic approach. Management Science, 31, 134-149

Gann, D. (2000). Building Innovation: Complex Constructs in a Changing World, Thomas Telford. Publishing, London.

Glasser, P. (1998). The knowledge Factor CIO, 15 December, PP. 1-20

Granter, Inc. (2006). About Granter. Stamford, CT. [Online] Available: http://www.granter.Com/it/about =granter. Jsp.(May 17, 2006)

Hearington, D. (2006). Factors that Impact the Instructional and Technical Support Provided by site-based Technology Coordinators in k-12 Schools. Unpublished doctoral dissertation University of Nevada, Las Vegas.

Heys, J.P. (2006). The theory \& practice of change management. Palgrave Macmillan [Online] Available: www.palgrave.com

Issa, R.A.I., Haddad, J. (2007). Perceptions of the Impacts of Organizational Culture and Information Technology on Knowledge Sharing in Construction: Rinker School of Building Construction, University of Florida, Gainesville, Florida, USA.

Mathieu, J. E. \& Zajac, D. (1990). A review and meta analysis of the antecedents, correlates and consequences of organizational commitment. Psychological Bulletin. 108, 171- 194

Mathieu, J.E. \& Farr, J.L. (1991). Further evidence for the discriminate Validity of measures of organizational commitment, Job involvement and job satisfaction. Journal of Applied Psychology, 76, 127-133. doi:10.1037/0021-9010.76.1.127, http://dx.doi.org/10.1037/0021-9010.76.1.127

Mayole, k. (2004). Total Cost of Ownership and Open Source Software. Department of education and children Services Adelaide, Australia. 
McMahan, G. (1993). The effects of changing information technology: An investigation of the motivational impact of information technology on jobs. Unpublished doctoral dissertation, Department of Management, Texas A\&M University.

Mester, C., Visser, D., Roodt, G. \& Kellerman, R. (2003). Leadership style and its relation to employee attitudes and behavior. SA Journal of Industrial Psychology, 29(2), 72-82

Meyer, J.P. \& Allen, N.J. (1987). A three components conceptualization of organizational Commitment. Journal of Applied Psychology. 61-75.

Meyer, J.P. \& Allen, N.J. (1991). A three component conceptualization of organizational Commitment. Human Resources Management Review, 1, 61-89. doi:10.1016/1053-4822(91)90011-Z, http://dx.doi.org/10.1016/1053-4822(91)90011-Z

Meyer, J.P. \& Allen, N.J. (1997).Commitment in the workplace: Theory, research and application. Thousand Oaks, CA: sage.

Meyer, J.P., Allen, N.J. \& Smith, C.A. (1993). Commitment to organizations and occupations: Extension and test of three component conceptualization. Journal of Applied Psychology, 78, 538-557

Meyer, J.P. \& Herscovitch, L. (2001). Commitment in the work place: Toward a general model. Human Resources Management Review, 11, 299-326. doi:10.1016/S1053-4822(00)00053-X, http://dx.doi.org/10.1016/S1053-4822(00)00053-X

Morrow, P.C. \& McElory, J.C. (1986). On assessing measures of work commitment. Journal of Occupational Behavior, 7, 139- 145

Mueller, C.W., Wallance, J.E. \& Price, J.L. (1992). Employee commitment: Resolving Some issues. Work and Occupations, 19, 211-236

Nonaka, I. and Takeuchi, H. (1995). The Knowledge Creating Company, Oxford University Press, New York, N Y.

Pan, S. \& Scarbrough, H. (1998). A Socio - technical view of knowledge - sharing at Buckman Laboratories, Journal of Knowledge Management, Vol. 2 No. 1, 55-66

Rhodes, S.R. \& Steers, R.M. (1981). Conventional versus worker- owned firms. Human Relations, 34, 1013-1035. doi :10.1177/001872678103401201, http://dx.doi.org/10.1177/001872678103401201

Robbins, S.P. (1998). Organizational Beharior : Concepts, Controversies and Application; Eight edition, Englewood Cliffs; N J. Prentice - Hall ,Inc.

Scholl, R.W. (1981). Differentiating commitment from expectancy as motivating force.Academy of Management Review, 6, 589- 599

Sethi, V., Meinert, D., King, R. C. \& Sethi, V. (1996). The multidimensional nature of organizational commitment among information systems Personnel. [Online] Available: http://hsb.baylor.deu/ram sower/ ais. ac.96/papers/sethi. $\mathrm{htm}(03 / 10 / 2001)$.

Storm, L. \& Roodt, G. (2002). Die Verband Tussen organisasies Osial Isering en Organisasiever Bondenheid. Tydskrif Vir Bedryfsiclkunde, 28(1), 14-21

Supar, N., Ibrahim, A. A., Mohamed, Z.A., Yahya, M. and Abdul, M. (2005). "Factors affecting knowledge sharing and its effects on performance: A study of three selected higher academic institutions", Proceedings, International Conference on knowledge Management. (ICKM), Kuala Lumpur, Malaysia.

Tamilson, A. (2002). High technology workers want respect:Surrey. Canadian Human Resources Reporter, 15(3), 2. Van Beveren, J. (2002). A model of knowledge acquisition that refocuses knowledge management, Journal of Knowledge management, 6. 1, PP. 18-22

Wall, T.D., Corbett, J.M., Martin, R., Clegg, C.W., \& Jackson, P.R. (1990). Advanced manufacturing technology, work design, and performance: A change study. Journal of Applied psycho logy, 75, 691-697, doi:10.1037/0021-9010.75.6.691, http://dx.doi.org/10.1037/0021-9010.75.6.691

Zuboff, S. (1988). In the age of the smart machine: The future of work and power. New York: Basic Books. 


\section{Appendix}

Table 1. Results of fitting regression coefficient models for pure and impure weights of the relation between the component support for information technology system and dimensions of organizational commitment in the University of Isfahan.

\begin{tabular}{|c|c|c|c|c|c|}
\hline Resource & $\begin{array}{c}\text { Standard } \\
\text { errors }\end{array}$ & $\begin{array}{c}\text { Regression } \\
\text { coefficient }\end{array}$ & $\mathrm{t}$ value & $\begin{array}{c}\text { Designation } \\
\text { coefficient }\end{array}$ & sig \\
\hline $\begin{array}{c}\text { Affective } \\
\text { commitment }\end{array}$ & 0.75 & -0.08 & 0.25 & 0.04 & 0.81 \\
\hline $\begin{array}{c}\text { Continuance } \\
\text { commitment }\end{array}$ & 0.98 & 0.09 & 0.13 & 0.04 & 0.89 \\
\hline $\begin{array}{c}\text { Normative } \\
\text { commitment }\end{array}$ & 1.40 & 0.02 & 0.02 & 0.04 & 0.98 \\
\hline
\end{tabular}

Table 2. Results of fitting regression coefficient models for pure and impure weights of the relation between the component access for information technology system with dimensions of organizational commitment in the University of Isfahan

\begin{tabular}{|c|c|c|c|c|c|}
\hline Resource & $\begin{array}{c}\text { Standard } \\
\text { errors }\end{array}$ & $\begin{array}{c}\text { Regression } \\
\text { coefficient }\end{array}$ & t value & $\begin{array}{c}\text { Designation } \\
\text { coefficient }\end{array}$ & sig \\
\hline $\begin{array}{c}\text { Affective } \\
\text { commitment }\end{array}$ & 0.45 & -0.07 & 0.23 & 0.01 & 0.82 \\
\hline $\begin{array}{c}\text { Continuance } \\
\text { commitment }\end{array}$ & 0.77 & 0.45 & 0.81 & 0.01 & 0.42 \\
\hline $\begin{array}{c}\text { Normative } \\
\text { commitment }\end{array}$ & 1.10 & -0.48 & 0.62 & 0.01 & 0.53 \\
\hline
\end{tabular}

Table 3. Results of fitting regression coefficient models for pure and impure weights of the relation between the component fit for information technology system and dimensions of organizational commitment in the University of Isfahan

\begin{tabular}{|c|c|c|c|c|c|}
\hline Resource & $\begin{array}{c}\text { Standard } \\
\text { errors }\end{array}$ & $\begin{array}{c}\text { Regression } \\
\text { coefficient }\end{array}$ & t value & $\begin{array}{c}\text { Designation } \\
\text { coefficient }\end{array}$ & sig \\
\hline $\begin{array}{c}\text { Affective } \\
\text { commitment }\end{array}$ & 0.095 & 0.090 & 1.17 & 0.07 & 0.25 \\
\hline $\begin{array}{c}\text { Continuance } \\
\text { commitment }\end{array}$ & 0.16 & 0.80 & 4.95 & 0.94 & 0.001 \\
\hline $\begin{array}{c}\text { Normative } \\
\text { commitment }\end{array}$ & 0.22 & 0.085 & 0.46 & 0.07 & 0.65 \\
\hline
\end{tabular}


Table 4. Results of fitting regression coefficient models for pure and impure weights of the relation between the component training for information technology system with dimensions of organizational commitment in the University of Isfahan.

\begin{tabular}{|c|c|c|c|c|c|}
\hline Resource & $\begin{array}{c}\text { Standard } \\
\text { errors }\end{array}$ & $\begin{array}{c}\text { Regression } \\
\text { coefficient }\end{array}$ & $\mathrm{t}$ value & $\begin{array}{c}\text { Designation } \\
\text { coefficient }\end{array}$ & $\mathrm{sig}$ \\
\hline $\begin{array}{c}\text { Affective } \\
\text { commitment }\end{array}$ & 0.17 & 0.10 & 0.67 & 0.03 & 0.51 \\
\hline $\begin{array}{c}\text { Continuance } \\
\text { commitment }\end{array}$ & 0.29 & 0.78 & 2.55 & 0.79 & 0.013 \\
\hline $\begin{array}{c}\text { Normative } \\
\text { commitment }\end{array}$ & 0.42 & 0.03 & 0.07 & 0.03 & 0.94 \\
\hline
\end{tabular}

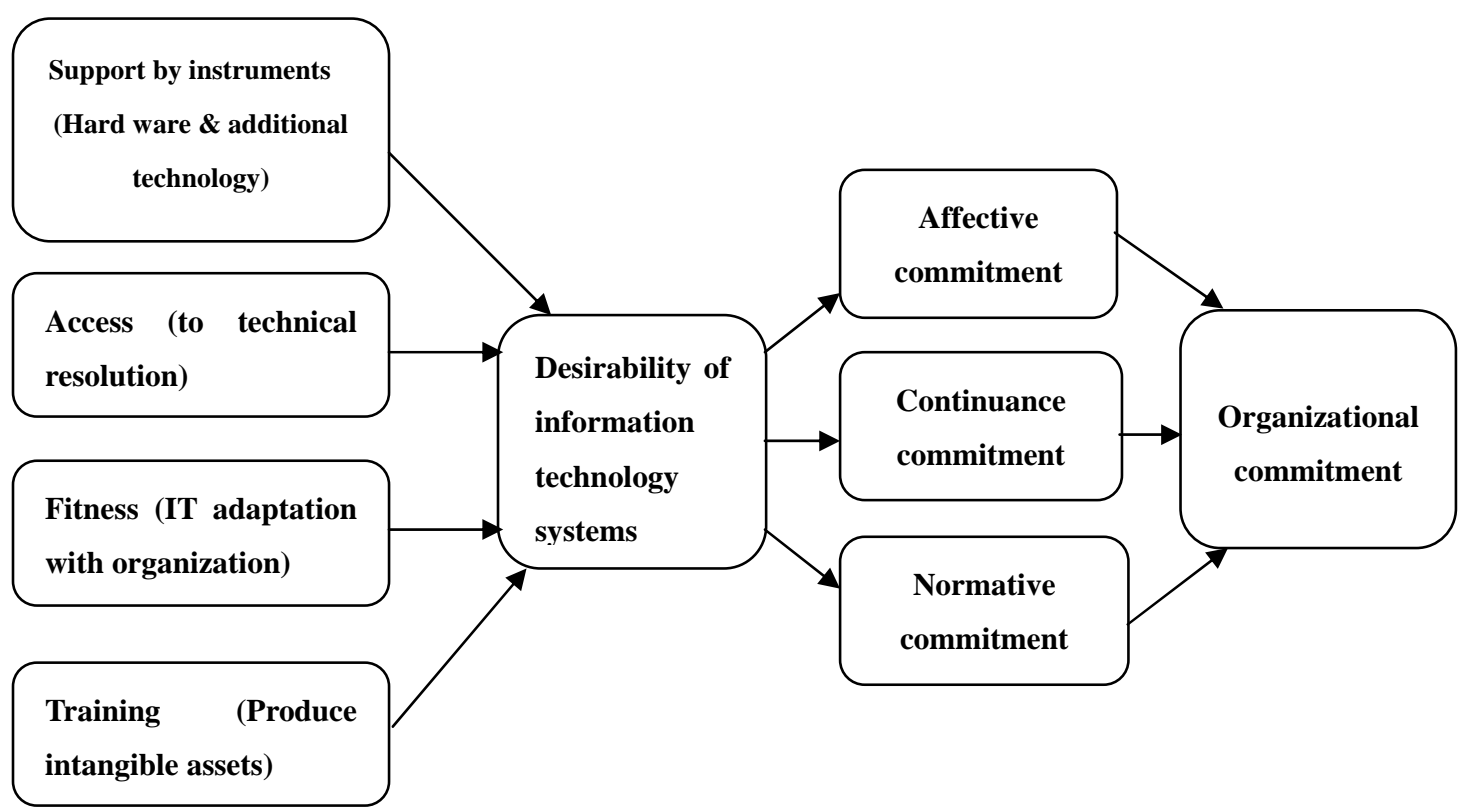

Figure 1. Proposed research framework

(A mixed model, based on Meyer \& Allen: 1991, and Writers: 2010) 


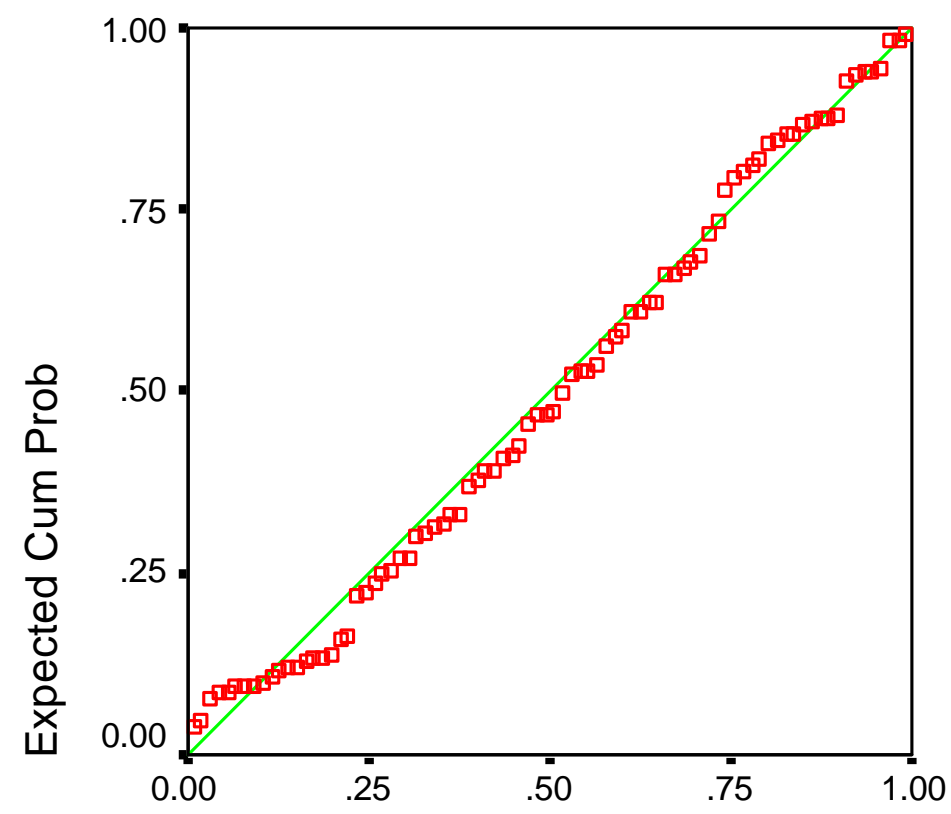

Observed Cum Prob

Figure2. Normal P-P Plot of Regression Stand: Dependent Variable: Support

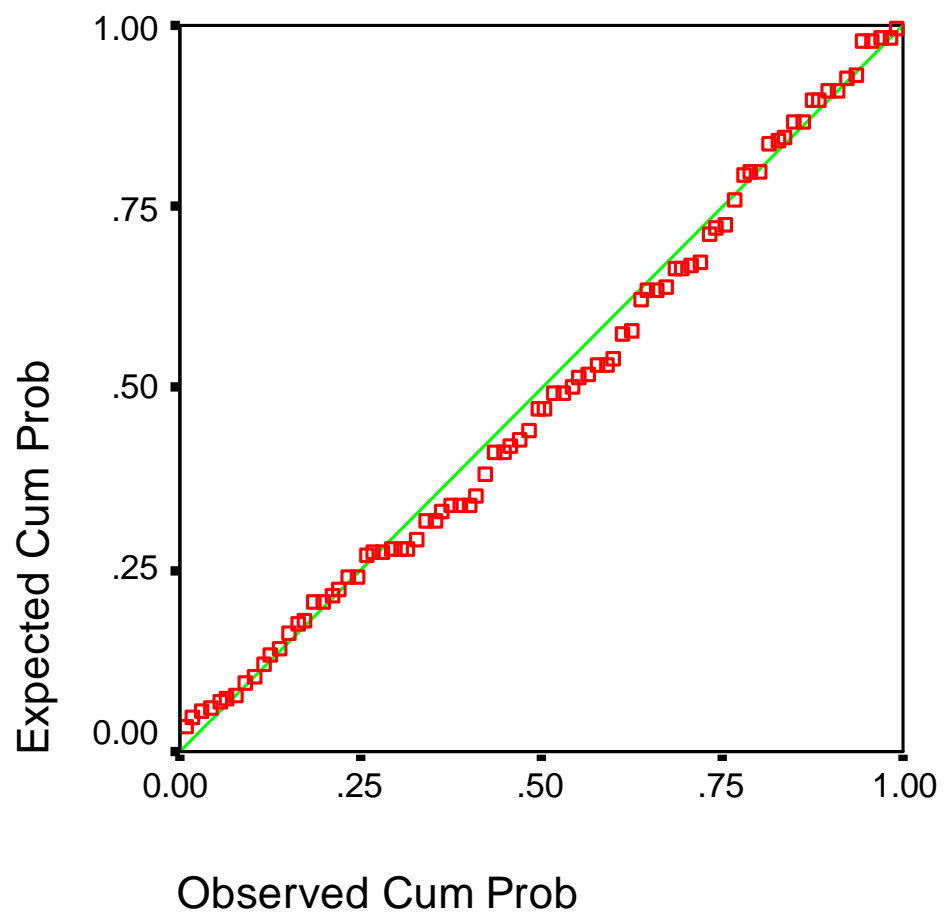

Figure3. Normal P-P Plot of Regression Stand: Dependent Variable: Access 


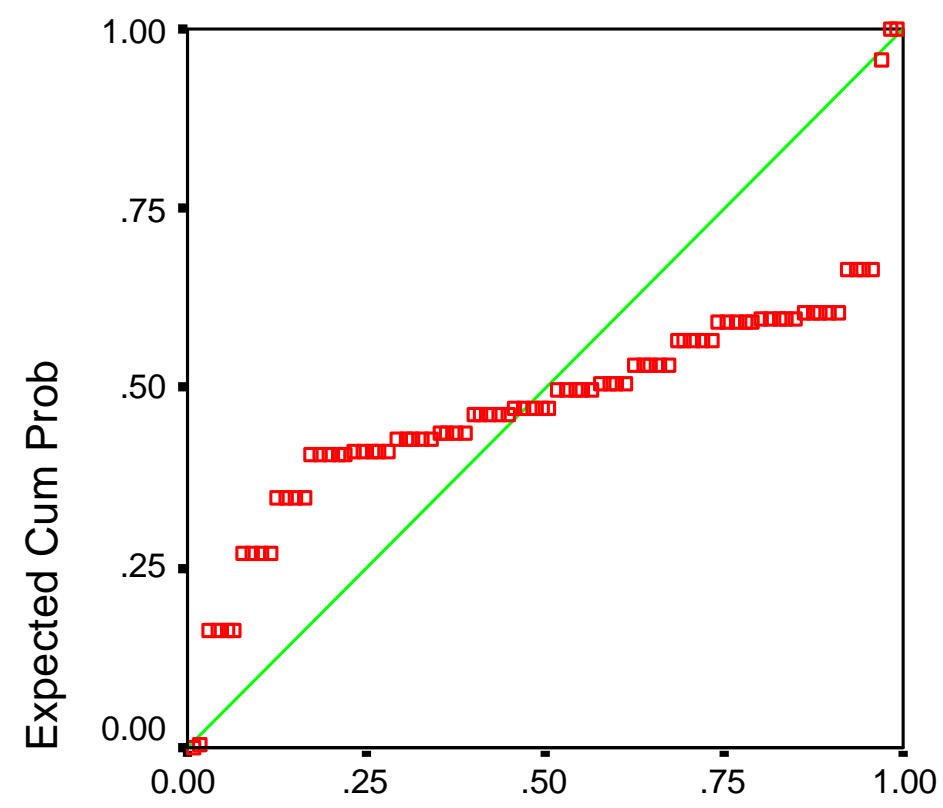

\section{Observed Cum Prob}

Figure4. Normal P-P Plot of Regression Stand: Dependent Variable: Fitness

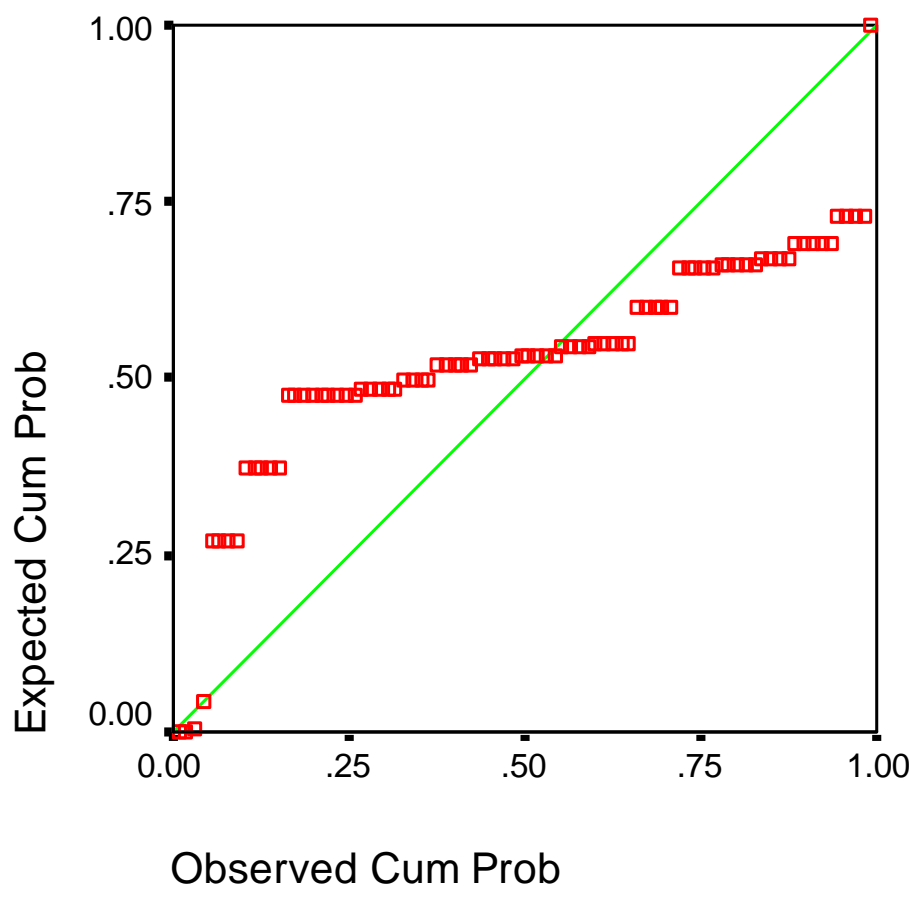

Figure5. Normal P-P Plot of Regression Stand: Dependent Variable: Training 